\title{
KEBERADAAN BISNIS WARALABA BERKAITAN DENGAN HAKI YANG DIMILIKI OLEH PIHAK PEMBERI WARALABA PADA UMKM (DI KOTA YOGYAKARTA)
}

\author{
Siti Sumartiah
}

\begin{abstract}
One form of development and expansion of business by using the Franchise system, so rapidly growing supported business expanding increasingly varied. Business approach through Franchise system is one of the strategy of empowering SME to develop business and improve SME in the future. Based on the description of the above mentioned background, it can be formulated the following issues: how the Franchise business regulatory system in the aspect of the agreement / contract, how the form of legal protection terwaralaba and how the efforts undertaken by SMEs as perpetrators of the Franchise in resolving disputes arising from the implementation Franchise agreement In connection with the development and protection of SME business as stipulated through Law No.20 Year 2009 on Small Business which stated that the government intends to seek and empower SMEs in order to compete in facing free trade. The empowerment of MSMEs is done through Partnership program as outlined in PP No.44 of 1997. From the existing Franchise contract, we can see the role of Franchise in arrangement of agreement / contract on Franchise business. But in practice the arrangement of agreement arrangements is more dominant by Franchisors who override the interests of Franchise recipients.
\end{abstract}

Keywords: Franchise, Intellectual Property Right, SME

\begin{abstract}
ABSTRAK
Salah satu bentuk pengembangan dan upaya memperluas bisnis dengan menggunakan sistem Franchise, begitu pesat berkembang didukung usaha memperluas bisnis kian bervariasi. Pendekatan bisnis melalui sistem Franchise merupakan salah satu strategi pemberdayaan UMKM untuk mengembangkan usaha dan meningkatkan UMKM dimasa yang akan datang. Berdasarkan uraian dari latar belakang tsb diatas, maka dapat dirumuskan permasalahanpermasalahan sebagai berikut: bagaimana sistem pengaturan bisnis Franchise dalam aspek perjanjian / kontraknya, bagaimana bentuk perlindungan hukum terwaralaba dan bagaimana upaya yang dilakukan oleh UMKM sebagai pelaku Franchise dalam menyelesaikan sengketa yang timbul dari pelaksanaan perjanjian Franchise Sehubungan dengan pengembangan dan perlindungan usaha UMKM yang dituangkan melalui UU No.20 Tahun 2009 tentang Usaha Kecil dimana dinyatakan bahwa pemerintah bermaksud untuk mengupayakan dan memberdayakan UMKM agar dapat bersaing dalam menghadapi perdagangan bebas. Pemberdayaan UMKM dilakukan dengan melalui program Kemitraan yang dituangkan pada PP No.44 Tahun 1997. Dari kontrak Franchise yang ada, dapat kita lihat peran Franchise dalam pengaturan perjanjian/ kontrak pada bisnis Franchise. Tetapi dalam praktek lapangan pengaturan perjanjian lebih dominan oleh Franchisor yang mengesampingkan kepentingan penerima Franchise.
\end{abstract}

Kata kunci : Waralaba, HAKI, UMKM 


\section{Latar Belakang}

Pengembangan Usaha melalui Franchise atau Waralaba ini terasa semakin banyak diterapkan oleh perusahaan didunia. Popularitas pada usaha Franchise sebagai suatu cara pemasaran dan distribusi barang dan jasa semakin meningkat. Sebagai salah satu sistem pemasaran yang efektif, keberadaan Franchise/Waralaba dianggap mampu menjangkau pangsa pasar suatu jenis produk keseluruh dunia tanpa harus memerlukan modal yang berisiko yang relatif tidak terlalu tinggi. Dalam rangka meningkatkan pembinaan usaha dengan Waralaba di seluruh Indonesia, maka perlu mendorong pengusaha nasional terutama pengusaha kecil dan menengah untuk tumbuh sebagai pemberi Waralaba Nasional yang handal dan mempunyai daya saing didalam negeri dan luar negeri khususnya produk dalam negeri.

Praktek bisnis Waralaba perlu mengetahui legalitas dan bonafitas usaha dari Pemberi Waralaba (franchisor) di Indonesia, guna menciptakan transparansi informasi usaha yang dapat dimanfaatkan secara optimal oleh usaha nasional dalam memasarkan barang dan/atau jasa dengan system Waralaba. Disamping itu sebelum membuat perjanjian Waralaba dengan penerima Waralaba (franchisee), pemberi Waralaba harus menyampaikan prospektus penawaran kepada calon penerima Waralaba dalam memasarkan produknya. Selain itu beberapa pengusaha Indonesia, khususnya Kota Yogyakarta juga telah mengembangkan bisnis waralaba, Semakin derasnya perkembangan Waralaba ditingkat UMKM pada saat ini menunjukkan bahwa lembaga bisnis ini dibutuhkan masyarakat.

Tetapi kenyataannya didalam praktek kontrak atau perjanjian Waralaba masih sering terjadi antara Pemberi hak dan Penerima hak terasa berat sebelah. Sehingga kurang menguntungkan bagi penerima hak waralaba dalam hal ini misalnya kita lihat dalam pengakhiran perjanjian, banyak pemberi hak Waralaba tanpa harus merugikan dirinya untuk dapat melakukan pengakhiran perjanjian tersebut . Dalam hal terjadi penutupan perjanjian Waralaba, dimana jangka waktu perjanjian telah habis dan Pemberi Waralaba tidak bersedia memperbaruinya, bahkan mengalihkan usaha waralabanya kepada orang lain. Dalam kondisi yang demikian, terasa tidak seimbang, karena tidak mempunyai kekuatan tawar menawar.

Dengan berlakunya Peraturan Pemerintah Republik Indonesia Nomor 42 tahun 2007, apakah sudah dapat menciptakan iklim yang kondusif bagi terwujudnya kemitraan, untuk menciptakan persaingan yang sehat dan sejauh mungkin dapat mencegah timbulnya keadaan yang merugikan khususnya Penerima hak dan pada umumnya perekonomian Nasional. Dengan uraian tersebut diatas penulis tertarik untuk meneliti tentang Kemitraan Bisnis ditinjau dari Aspek Hukum, yaitu khusus pada usaha Bisnis Waralaba UMKM. Berdasarkan latar belakang masalah diatas, maka dapat dirumuskan permasalahan sebagai berikut :

1. Bagaimana Kekuatan hukum dari perjanjian bentuk perjanjian Waralaba dikaitkan dengan HAKI yang diberikan oleh pihak pemberi Waralaba?

2. Bagaimana kedudukan Pemberi dan Penerima Waralaba dikaitkan dengan HAKI ?

3. Bagaimana upaya yang dilakukan oleh UMKM sebagai pelaku Waralaba dalam menyelesaikan sengketa yang timbul dari pelaksanaan perjanjian Waralaba?

\section{Pengertian Waralaba di Indonesia}

Waralaba merupakan hak khusus yang dimiliki oleh orang perorangan atau badan usaha terhadap sistem bisnis dengan ciri khas usaha dalam rangka memasarkan 
barang dan/atau digunakan oleh pihak lain berdasarkan perjanjian Waralaba ( Peraturan Pemerintah No.42 Th 2007, Psl 1 angka 1 )

Waralaba mampu menciptakan lapangan kerja baru dan menyerap tenaga kerja.banyak.

Pemberi Waralaba / Franchisor Adalah orang perorangan atau badan Usaha yang memberikan hak untuk memanfaatkan dan/atau menggunakan Waralaba yang dimilikinya kepada penerima Waralaba

Kewajiban Pemberi waralaba harus memberikan prospektus penawaran waralaba kepada calon Penerima Waralaba pada saat melakukan penawaran. Penerima Waralaba / Franchisee Adalah orang perorangan atau badan usaha yang diberikan hak oleh Pemberi Waralaba untuk memanfaatkan dan/atau menggunakan Waralaba yang dimiliki Pemberi Waralaba. Hak Kekayaan Intelektual, disingkat "HAKI". Merupakan padanan kata yang biasa digunakan untuk Intellectual Property Rights (IPR), yakni hak yang timbul bagi hasil olah pikir yang menghasikan suatu produk atau proses yang berguna untuk manusia pada intinya HAKI adalah hak untuk menikmati secara ekonomis hasil dari suatu kreativitas intelektual. Rahasia dagang Suatu karya yang tidak diketahui oleh umum di bidang teknologi dan / atau bisnis dimana mempunyai nilai ekonomis karena berguna dalam kegiatan usaha, dan dijaga kerahasiaannya oleh pemilik rahasia dagang. Perjanjian Waralaba Pengertian perjanjian adalah perjanjian secara tertulis antara pemberi Waralaba dengan penerima Waralaba (Peraturan Pemerintah No.42 Th 2007, tentang Waralaba, (Pasal 4)

\section{Dasar hukum perjanjian Waralaba di Indonesia}
a. Pasal 5 ayat (2) UUD Negara RI Tahun 1945
b. KUHPerdata
c. Undang-Undang RI Nomor 9 Tahun 1995 tentang Usaha Kecil

d. Peraturan Pemerintah RI Nomor 44 tahun 1997 tentang Kemitraan

e. Peraturan Pemerintah No 42 tahun 2007 tentang Waralaba

f. Undang Undang no 15 tahun 2001 tentang Merek

g. Undang Undang No 30 tahun 2000 tentang Rahasia Dagang

Perlindungan Hukum Pada umumnya keberadaan hukum adalah merupakan perlindungan untuk kepentingan manusia yang berbentuk kaidah atau norma. 11.STPW (Surat Tanda Pendaftaran Waralaba)

\section{Tujuan Penelitian}

Berdasarkan pada pokok permasalahan tersebut diatas, maka setiap kegiatan bersifat ilmiah tentunya mempunyai tujuan tertentu. Demikian pula dengan penelitian ini bertujuan :

a. Untuk mengetahui lebih lanjut tentang kriteria perjanjian Waralaba terkait HAKI yang terdaftar

b. Untuk menganalisis dan memahami kedudukan pemberi Waralaba dan penerima Waralaba yang dikaitkan dengan HAKI

c. Untuk mengetahui upaya yang dilakukan oleh UMKM sebagai pelaku Waralaba dalam menyelesaikan sengketa yang timbul dari pelaksanaan perjanjian Waralaba.

\section{Manfaat Penelitian}

Diharapkan bahwa hasil penelitian ini akan dapat memberikan manfaat bagi :

a. Dapat menjadi pertimbangan dan masukan bagi Lembaga Legislatif dalam merumuskan Undang undang

b. Dapat memberikan manfaat bagi para pelaku usaha Waralaba 
c. Dapat memberi jalan keluar yang akurat terhadap permasalahanpermasalahan yang dihadapi.

Tempat Dan Waktu Penelitian Tempat Penelitian di lakukan di Kota Yogyakarta. Waktu Penelitian dilakukan selama 3 (tiga) bulan

Subyek Dan Obyek Penelitian Subyek Penelitian adalah Pemberi Waralaba dan Penerima Waralaba. Obyek Penelitian adalah perjanjian Bisnis Waralaba pada UMKM.

Pelaksanaan Penelitian Penelitian ini dengan pendekatan yuridis normatif dan empiris yaitu penelitian terhadap ketentuan atau peraturan perundang-undangan dan penelitian bertitik tolak dari data primer yaitu data yang didapat langsung dari masyarakat sebagai sumber pertama melalui lapangan dan dari kepustakaan. Sedangkan bentuk dari laporan penelitian ini nanti adalah bersifat deskriptif.

Populasi Penelitian Populasi dari penelitian adalah meliputi pelaku usaha bisnis Waralaba (UMKM) yang melakukan kontrak Waralaba dalam wilayah penelitian dilakukan.

Sampel Penelitian Populasi dalam penelitian ini digunakan sebesar 30 pelaku usaha sebagai responden yaitu penerima waralaba dan pemberi Waralaba.

Penelitian ini dilakukan untuk memperoleh data data yang

meliputi :

\section{Data Primer}

Penelitian lapangan dalam pengumpulan data dengan menggunakan : Kuisioner dan wawancara pemberi waralaba dan penerima waralaba

\section{Data Sekunder}

Penelitian kepustakaan ini untuk mendapatkan data sekunder tentang hukum perjanjian, Undang-undang berkaitan dengan sistem Waralaba

\section{Analisis Data}

Dari data yang ada diperoleh melalui penelitian kepustakaan dan lapangan, akan dianalisis secara kualitatif.

\section{Hasil Penelitian}

Dalam bagian ini disajikan pembahasan hasil penelitian Berdasar pada penelitian terhadap pelaku Waralaba/ franchise yang diteliti, peneliti membatasi pada penerima Waralaba dengan kerjasama pada bisnis Waralaba, maksimal besarnya kontrak/ perjanjian sejumlah Rp.10.000.000,Semakin derasnya perkembangan Waralaba ditingkat UMKM pada saat ini, menunjukkan bahwa lembaga bisnis ini dibutuhkan masyarakat dan sekaligus memberi kesempatan masyarakat dalam meningkatkan kesejahteraan serta pendapatan. Kenyataan dari hasil penelitian lapangan hubungan antara pemberi waralaba dan penerima waralaba dalam perjanjian bisnis Waralaba ditandai dengan ketidak seimbangan kekuatan tawar secara tertulis yang dibuat dan ditawarkan oleh pihak pemberi waralaba/franchisor dan penerima waralaba/franchisee yang menetapkan secara apriori syarat2. baku yang harus diikuti oleh penerima waralaba.

Dari bentuk perjanjian diatas, ada beberapa penyebab timbulnya ketidak seimbangan penerima Waralaba dalam perjanjian bisnis Waralaba yaitu dikarenakan status penerima waralaba adalah berada dipihak yang lebih lemah. dari bentuk perjanjian diatas, ada beberapa penyebab timbulnya ketidak seimbangan penerima waralaba dalam perjanjian waralaba. Faktor faktor itu meliputi: Pertama, lemahnya posisi tawar dari pihak penerima waralaba hanya diberi kesempatan untuk menerima atau menolak perjanjian waralaba. Kedua, ketidak pengertian pihak penerima waralaba terhadap persoalan-persoalan hukum diseputar waralaba. Dengan demikian penerima waralaba tidak ada 
kemungkinan melakukan tawar menawar dari isi perjanjian, apabila isi perjanjian itu masih sejalan dengan prinsip-prinsip umum dari perjanjian. Misalnya mengenai jumlah fee, cara pembayaran, batas-batas ekslusif daerah usahanya. Pada pemberi waralaba/franchisor lebih kuat dari pada penerima Waralaba/ franchisee.

Disamping pemberi waralaba / franchisor sudah banyak pengalaman dalam menangani usaha waralaba ini, sehingga dalam hal ini dapat dikatakan pengetahuan yang dimiliki lebih unggul ketimbang pengetahuan dari penerima waralaba. Hal ini mengakibatkan adanya ketidak seimbangan antara pihak pemberi waralaba dan penerima waralaba dalam pembuatan perjanjian waralaba. Beberapa hal yang menyangkut manajemen produksi dan pelayanan yang ditawarkan oleh pihak franchisor yang penting dalam kegiatan pelatihan dan promosi.

Dalam kajian yuridis perjanjian waralaba dipandang perjanjian lisensi khusus, karena menyangkut lisensi merek atau trade mark dan merek jasa atau dapat juga dikatakan sebagai pemberian hak lisensi untuk memproduksi produk dengan merek tertentu untuk mendistribusikan produk tertentu.

Dengan kata lain karena adanya suatu kewenangan dari pihak franchisor untuk melakukan pengawasan terhadap bisnis kerjasama yang dilisensikan pada franchisee, termasuk pelatihan serta perdagangan dan manajemen. Adapun dalam pelaksanaannya hanya dilakukan sebatas ketentuan yang termuat dalam perjanjian sebagaimana yang telah direncanakan sebelumnya, serta mengacu pada sistem yang ditentukan oleh franchisor. Dalam hal ini memberikan pengertian bahwa franchisee dalam melakukan kegiatan yang berkaitan dengan system bisnis waralaba yang harus memenuhi standarisasi.
Pada penelitian ini telah ditemukan adanya suatu perjanjian Waralaba yang telah disepakati oleh para pemberi waralaba dan penerima waralaba dan dalam perjanjian tersebut terdapat kewajiban kewajiban yang harus dipenuhi masing masing pihak. Namun penerima Waralaba telah melakukan wanprestasi dengan ketentuan misalnya ( pasal 12 ) dalam perjanjian tersebut dengan cara melakukan pengalihan pelaksanaan perjanjian waralaba kepada pihak lain tanpa seijin pemberi waralaba, sehingga disini menimbulkan pertentangan kepentingan pada pelaksanaan perjanjian waralaba. Sedangkan tujuan dari penelitian ini adalah untuk mengetahui bentuk wanprestasi yang dilakukan oleh penerima waralaba pada perjanjian waralaba di Jogyakarta dan untuk mengetahui akibat hukum yang timbul karena wanprestasi terhadap penerima waralaba pada perjanjian waralaba, serta untuk mengetahui upaya hukum terhadap pelaksanaan pengalihan perjanjian pada perjanjian waralaba yang dapat berakibat terhadap penerima waralaba berupa penuntutan ganti rugi, biaya kemitraan dan pemutusan perjanjian waralaba secara sepihak, namun pemberi waralaba tidak pernah melakukan penuntutan ganti rugi, sedangkan upaya hukum yang ditempuh ialah dengan cara musyawarah / mufakat oleh kedua belah pihak dengan dilakukannya peneguran terlebih dahulu sebanyak satu kali oleh pemberi waralaba.

Orang yang telah membeli bisnis waralaba bisa mendapatkan keuntungan kerjasama yang telah terbangun sebelumnya oleh pemilik waralaba, misal kerjasama dengan pemasok bahan baku, pihak periklanan dan juga pemasaran . Dan dalam hal ini banyak orang berpikir bahwa keuntungan bisnis waralaba adalah mendapatkan keuntungan lebih besar karena brand atau merek telah dikenal oleh banyak orang . Akan tetapi kenyataan nya hal ini tidak selalu terjadi demikian. Biaya yang dikeluarkan oleh pembeli waralaba 
pada pemilik waralaba tentunya dipotong dari keuntungan yang didapat pembeli waralaba dan akan mendapatkan banyak kemudahan disaat awal usaha,

Salah satu kekurangan dari bisnis waralaba adalah kurangnya kendali dari pembeli waralaba terhadap bisnisnya sendiri, karena semua sistem telah ditentukan pemilik waralaba, sehingga ruang gerak pembeli waralaba sangat terbatas dan Ide-ide untuk kreatifitaspun terkadang tidak bisa diaplikasikan, karena adanya perjanjian perjanjian khusus \& sangat terikat dengan suplier untuk mendapatkan keuntungan yang mencukupi.

Ketergantungan pada reputasi waralaba lain salah satu kekurangan terbesar dari waralaba adalah ketergantungannya reputasi waralaba terhadap waralaba lain. Jika waralaba yang lain melakukan kesalahan yang mengakibatkan rusaknya reputasi, maka hal ini juga akan mempengaruhi waralaba yang dikelola

Bentuk Perlindungan Hukum Penerima waralaba UMKM Penerima waralaba, dalam mekanisme kerja dalam perjanjian waralaba berdasarkan prinsip kesetaraan dan saling menguntungkan, kedudukan pemberi waralaba dengan penerima waralaba setara. Hal ini akan menggambarkan dalam skala perusahaan, masing-masing perusahaan yang dimilikinya dan dikendalikan oleh pemiliknya. Antara kedua belah pihak merupakan pihak yang bebas antara satu dengan lainnya, meskipun secara ekonomis keduanya merupakan unit yang saling bergantung dalam suatu sistem.

Dalam kenyataannya dari hasil penelitian lapangan hubungan pemberi waralaba dan penerima waralaba dalam bentuk perjanjian waralaba, kebanyakan merupakan perjanjian baku /standart yang dibuat dan ditawarkan oleh pemberi waralaba. Pemberi waralaba yang menetapkan secara apriori syarat-syarat baku yang harus diikuti oleh penerima waralaba/franchisee

Bentuk pelaksanaan Peraturan Pemerintah RI No.42 tahun 2007 tentang waralaba jo SK Menperindag No 259/MPP/Kep/7/1997 dalam mencegah terjadinya pelanggaran pemberi waralaba / franchisor.

Pelaksanaan PP No.42 tahun 2007 dalam prakteknya, secara umum dapat memberikan keseimbangan antara pihak penerima waralaba dengan pemberi waralaba. Pasal 4 ayat (1) yang mengatur bahwa perjanjian waralaba harus dituangkan dalam bentuk perjanjian tertulis dengan memperhatikan hukum Indonesia dan sudah mulai dilaksanakan meskipun belum optimal.

Tidak optimalnya pelaksanaan PP No. 42 tahun 2007 tentang waralaba diindikasikan dengan munculnya ketidak tegasan pengenaan sanksi bagi para pelanggar peraturan Pemerintah tersebut.

Selanjutnya juga hal ini terilustrasi dalam persyaratan minimal pendaftaran waralaba Pasal 5 PP No.42 tahun 2007 mensyaratkan bahwa dalam perjanjian waralaba harus memuat 12 klasul. Dari 12 klasul ini sebagian besar sudah diterapkan dalam perjanjian kemitraan waralaba.

\section{Pembahasan}

Bentuk perjanjian bisnis waralaba, pada kenyataan dari hasil penelitian lapangan, hubungan antara pemberi waralaba/ franchisor dengan penerima waralaba/ franchisee dalam perjanjian bisnis waralaba ditandai dengan ketidak seimbangan kekuatan tawar menawar. Perjanjian waralaba yang diteliti merupakan perjanjian yang baku yang dibuat dan ditawarkan oleh pemberi waralaba. Dan pemberi waralaba/ franchisor yang menetapkan secara apriori syarat-syarat baku yang harus diikuti oleh penerima waralaba. 
Menurut ketentuan perjanjian waralaba dibuat dalam bentuk tertulis, agar menjamin kepastian hukum bagi pelaku usaha waralaba. Perjanjian waralaba/franchise pada prinsipnya merupakan hubungan hukum antara beberapa pihak yang sepakat untuk melakukan perbuatan hukum tertentu, disamping itu perjanjian kerjasama bisnis waralaba sebagai suatu perjanjian akan mengikat para pihak dan dapat dipaksakan secara hukum.

Dalam hal ini perjanjian waralaba yang terjadi antara Pewaralaba/ franchisor selaku pemilik dan sebagai UMKM dalam perjanjian Kerjasama Bisnis Waralaba, dalam perjanjian tersebut terdapat kekeliruan yaitu posisi Pewaralaba/ franchisor selaku pemilik, sementara dalam pasal 1 angka 3 perjanjian tersebut yang menjelaskan bahwa pemilik adalah badan usaha yang memberikan hak kepada pihak lain untuk dapat memanfaatkan dan menggunakan usaha yang dimiliki kepada penerima bisnis waralaba/ franchisee, jadi dalam hal ini kurang jelas bahwa pihak pewaralaba/ franchisor itu sebagai pemilik atau penerima perjanjian kemitraan bisnis waralaba. Sedangkan pada ketentuan yang menjadi pijakan hukum dalam hukum positif Indonesia, adalah perjanjian mengacu pasal 1320 KUHPdt. Akan tetapi terhadap pelaksanaan pada perjanjian bisnis waralaba sendiri berlandaskan dari pasal 1338 KUHPdt. Yang berkenaan dengan asas kebebasan berkontrak.

Sedangkan hukum kontrak di Indonesia menganut suatu"system terbuka"dalam hal ini memberikan kebebasan bagi setiap orang untuk membuat perjanjian/ kontrak terutama menyangkut isinya. Selain undang-undang tentang UMKM diterbitkan pula suatu pedoman pelaksanaan keterkaitan kemitraan di bidang industry kecil yang isinya memuat mengenai pedoman kemitraan yang dapat dilaksanakan dengan berbagai cara salah satunya dengan waralaba. Dalam hal ini dapat disampaikan secara singkat dapat diuraikan bahwa pedoman tersebut memuat mengenai pengertian waralaba, syarat dan kewajiban sebagai pemberi waralaba/ franchisor dan UMKM sebagai penerima waralaba/ franchisee, serta bidang usaha yang potensial dikembangkan dengan system waralaba. Hal ini merupakan langkah yang cukup positif dalam rangka melakukan pembinaan UMKM selaku Penerima waralaba.atu bisnis apakah memenuhi persyaratan

Dalam kenyataannya dalam $M O U$ adalah ringkasan dari perjanjian yang intinya memuat bahwa kedua belah pihak sepakat untuk meningkatkan diri dalam suatu Kerjasama Waralaba. Biasanya penandatanganan $M O U$ disertai dengan pembayaran tahap pertama Biaya Waralaba ( 20\% - 30\% )untuk mencegah calon terwaralaba "main-main" karena kita sudah mulai membuka"rahasia dapur" setelah MOU. Ada Klasul dalam MOU bahwa jika tidak dilanjutkan dengan penanda tanganan perjanjian Waralaba setelah 30 hari, maka $M O U$ menjadi batal dan uang yang telah dibayar tidak dapat ditarik kembali. Supaya fair, 14 hari sebelum penandatanganan, calon terwaralaba sudah harus menerima draft $M O U$ untuk dipelajari, dan menyiapkan untuk pembayaran tahap pertama. Setelah MOU tahap berikutnya adalah penandatanganan perjanjian Waralaba sedangkan perjanjian yang sudah ditandatangani mengikat selama masa berlakunya perjanjian.

Pada saat serah terima barang / SOP / Instalasi, harus ada Berita Acara serah terima, harus ada saksi dan dokumentasi sebagai bukti dan setelah serah terima kewajiban Penerima Waralaba untuk dapat menjaga barang / SOP pinjaman dari Pemberi Waralaba sesuai apa yang telah disepakati bersama tersebut. Dan pada saat itu akan disusul dengan pelunasan atau pembayaran terakhir sebelum penerima Waralaba dapat mulai membuka outletnya. 
Dalam persiapan opening perlu dipastikan semua kewajiban pembayaran sudah harus dilunasi oleh penerima Waralaba. Pada saat opening sangat disarankan pemberi Waralaba membantu mendampingi persiapan opening dan bentuk opening dapat disesuaikan dengan jenis usaha Waralaba yang akan dibuka dan bagi usaha yang sifatnya retail perlu melibatkan warga sekitarnya. Sedangkan promosi khusus opening perlu dilakukan missal dalam bentuk iklan di media lokal ( radio, surat kabar setempat, majalah), leaflet, spanduk / umbul-umbul dan perlu ada program diskon khusus opening)

Pendampingan Waralaba diperlukan untuk membantu memberikan kemudahan bagi penerima Waralaba dalam menjalankan bisnisnya sehingga dapat cepat menghasilkan keuntungan. Menjaga keseragaman yang menjadi ciri system Waralaba diantara outlet-outlet Waralaba milik penerima Waralaba dan tentunya dalam memonitor sehingga otomatis memudahkan pengambilan solusi jika terjadi masalah.

Permasalahan sering terjadi di lapangan antara lain adanya penyimpangan dari SOP misalnya perbedaan kualitas output, perbedaan penghitungan royalty akibat system administrasi tidak seragam, tampilan outlet tidak seragam, ketidak tepatan bentuk, ukuran, warna logo dan atribut identitas lainnya.

Masalah dengan penerima Waralaba dilapangan ditemukan penerima Waralaba merasa keberatan dengan besarnya royalty dan meminta diskon, keterlambatan penerima Waralaba dalam membayar royalty. Jadi perlu hati-hati dengan tidak membayar royalty fee sering hanya dijadikan "senjata" untuk menunjukkan ketidak puasan kepada pemberi Waralaba.

\footnotetext{
Mengenai masalah ketidak puasan pada pemberi Waralaba, terhadap penerima Waralaba antara lain tidak mendapatkan kontrol dan monitoring yang
}

dijanjikan, merasa tidak mendapatkan pelatihan berkala yang dijanjikan,merasa pemberi Waralaba disaat-saat sulit dan omzet tidak sesuai apa yang ditargetkan.

Sebagai tindak lanjut dalam rangka melakukan pembinaan terhadap pada umumnya pemahaman UMKM di Indonesia khususnya dalam hal penggunaan kerjasama bisnis waralaba dalam bidang makanan/ minuman, jasa. Dalam hal ini dalam rangka untuk memberikan semangat/ motivasi pertumbuhan dan pengembangan UMKM untuk dapat menerapkan memenuhi syarat di waralaba sistem waralaba.

Format bisnis waralaba/ franchise pada umumnya adalah suatu sistem untuk mempersiapkan suatu bisnis apakah telah memenuhi syarat diwaralaba UMKM dan peralatan

\section{Kesimpulan}

Berdasarkan hasil penelitian dan pembahasan dimuka, maka dapat disimpulkan bahwa bentuk perjanjian pada Bisnis Waralaba UMKM serta factor penyebabnya serta pelaksanaan Peraturan Pemerintah No 42 Tahun 2007 adalah sebagai berikut :

Pada dasarnya berbagai pengaturan franchise di Indonesia tidak diatur secara specific didalam ketentuan Perundangundangan tetapi diatur dalam sejumlah perundang-undangan, secara kontraktual franchise adalah suatu perjanjian yang dalam hal ini disebutkan sebagai perjanjian tidak bernama didalam Kitab UndangUndang Hukum Perdata, sebab dalam hal ini diberikan kebebasan para pihak untuk membuat perjanjian berdasarkan kesepakatan masing-masing. Sedangkan secara tehnis procedural pemerintah berusaha menetapkan peraturan yang berkaitan dengan franchise dengan keluarnya Peraturan Pemerintah No.42 Tahun 2007 tentang Waralaba yang telah 
disempurnakan, dalam peningkatkan kesejahteraan UMKM.

Untuk selanjutnya pengaturan franchise di Indonesia tetap berpegang pada ketentuan dasar dalam Kitab Undang-undang Hukum Perdata dan Peraturan Pemerintah No 42 Tahun 2007 tentang Waralaba.

Pada masalah ini kedudukan penerima Waralaba/ franchisee seringkali tidak seimbang dengan Pemberi Waralaba / franchisor dikarenakan dalam hal pembuatan perjanjian .

Pembuatan perjanjian selalu dilakukan oleh pihak franchisor, sehinggakeuntungan hanya berada ditangan franchisor, sedangkan franchisee sering mengalami ketidak puasan. Hal ini dapat dilihat dari pembayaran royalty \& fee dan lain-lain yang terkandung didalam perjanjian / kontrak tersebut, bahkan untuk pemilihan tempat,gerai usaha juga berdasarkan ketentuan franchisor. Dalam hal ini penyelesaian sengketa dilakukan dengan cara proses peradilan. Adapun sengketa antara franchisee dan franchisor belum pernah terjadi di Indonesia khususnya kota Yogyakarta,tetapi dalam kontrak atau perjanjian tegas dinyatakan bahwa penyelesaian sengketa dapat dilakukan dengan cara musyawarah dan apabila ada ketidak puasan, maka dapat diupayakan ketahap peradilan, sedangkan proses penyelesaian diluar indonesia dilakukan oleh para arbiter Internasionsi, karena pada umumnya sengketa franchise menyangkut hubungan luas dan bersifat Internasional

\section{Saran}

Berdasarkan kesimpulan dan wawancara serta pengamatan peneliti, maka peneliti memberikan saran-saran bagi penerima Waralaba/franchisee pada kegiatan Kerjasama Bisnis Waralaba UMKM hendaknya lebih memperhatikan beberapa hal, sehingga dapat mengoptimalkan kegiatan usahanya dan lebih berhati-hati
Berikut beberapa saran yang dapat diberikan sebagai berikut :

1. Sebelum menanda tangani perjanjian / kontrak harus bisa melihat :

a. Apakah bisnis tersebut ada keunikan/ keunggulan, bagaimana pengalaman pemiliknya dalam mengelola usahanya dan berdirinya kapan.

b. Didalam pembuatan Kontrak/ perjanjian hendaknya franchisor memperhatikan aspek kemanfaatan, bukan hanya bagi franchisee, terutama pada saat seorang franchisor mendirikan suatu jenis franchise khususnya untuk jenis franchise UMKM, maka perlu franchisor menyusun suatu perjanjian franchise yang mengandung manfaat bagi rasa keadilan dan UMKM yang terdiri dari pengusaha kecil. Penyusunan perjanjian kontrak harus membedakan apakah ditujukan untuk pengusaha UMKM atau pengusaha yang besar

c. Perlu dianalisa apakah usaha tersebut dalam kurun 5 tahun kebelakang prospeknya bagaimana.

d. Sebagai pembuatan perjanjian yang berdasarkan kesepakatan para pihak, maka perlu adanya satu pengaturan Perundang-undangan yang mengatur secara tegas berbagai aspek yang mengatur tentang franchise/ waralaba di Indonesia. Perlu adanya pembedaan antara peraturan umum tentang franchise, apakah franchise besar atau franchise UMKM

2. Hendaknya perselisihan diantara pemberi waralaba/ franchisor dan penerima waralaba / franchisee harus dapat dihindarkan mengingat biaya untuk berperkara di pengadilan mahal, sebaiknya setiap permasalahan hanya dilakukan dengan musyawarah/ negosiasi.

Apabila ada sengketa maka perlu dipilih suatu lembaga yang dapat bertindak sebagai negoisator, sehingga perkara dijamin kerahasiaannya tidak sampai ke Pengadilan. 


\section{DAFTAR PUSTAKA}

Anomi, 2006"Aspek Hukum Dari Franchise" Artikel dalam kliping

Perpustakaan, BPPM.

Bryce Webster, 2006, The Insiden's Guide to Franchising Amacom, American York.

Management Association, New

Biji Wijayanto, 2011, Memahami Bisnis Franchise, Pusat Pendidikan dan

Pelatihan Bisnis Waralaba,

Disperindagkop Propinsi DIY,

Yogyakarta.

Engenia Liliawati Mulyono, 2007, Peraturan PerUndang-Undangan

Waralaba

UU No 42 Tahun 2007 tentang Waralaba, Fokusmedia, Bandung.

Erman Rajagukguk, Ridwan Khairandy, 2006, Tehnologi dan Alih Tehnologi

Dalam Perspektif Hukum, Universitas Islam Indonesia, Yogyakarta.

Indag, 2000, Informasi tentang Waralaba Diperindag Dirjen Perdagangan

Dalam Negeri, Direktorat Bina Usaha, Jakarta.

Johny Ibrahim, 2007, Teori dan Metodologi Penelitian hukum Normatif, Citra

Aditya Bakti, Bandung

Koentjaraningrat, 2007, Metode-metode Penelitian Masyarakat, Prenada

Media, Jakarta

Richard Burton Simatupang, 2006, Aspek

Hukum Dalam Bisnis, Rineka Cipta,

Jakarta.

Sanusi Bintang dan Dahlan, 2001, Pokokpokok Hukum Ekonomi dan Bisnis,

Citra aditya Bakti, Bandung

Stephen Fox, 1993, Product Franchising dan Business Format Franchising,

Soesanto Boedidarmo, Media Komputindo, Jakarta.

Sumartiah Siti, 2001, Aspek Hukum Restoran Siap Saji di Indonesia, Tesis

Program Magister Ilmu Hukum

Universitas Islam Indonesia, Yogyakarta
Subagio, Felix, 2003, Perlindungan Bisnis Franchise, Institut Pendidikan dan Pembinaan Manajemen, Jakarta

Suharnoko, Desember 1996, Pemutusan Perjanjian dan Perlindungan Hukum bagi Franchise, Hukum Ekonomi Pembangunan No.6 Th XXVI, Jakarta.

Diklat Manajemen Binis Waralaba, 2011, Pusat Pendidikan dan Pelatihan Bisnis

Waralaba, Disperindagkop Propinsi DIY.

Kitab Undang-undang Hukum Perdata Undang-Undang Republik Indonewsia nomor 42 Tahun 2007 tentang Waralaba

Undang-Undang Republik Indonesia Nomor 9 tahun 1995 tentang Usaha Kecil

Peraturan Men. Perdag. RI. No.259 / MPP / Kep / 7/ 1997 tentang

Ketentuan Tata Cara Pelaksanaan

Pendaftaran Usaha Waralaba

Undang-Undang Republik Indonesia

Nomor 20 tahun 2008 tentang Usaha

Mikro, Kecil, dan Menengah

Peraturan Pemerintah RI No.44 Tahun 1997 tentang Kemitraan

Permen Perdag. Nomer 31/ M-

Dag/ Per/ 8/ 2008 tentang

penyelenggaraan Waralaba Tata

Cara Penerbitan Surat Tanda

Pendaftaran Usaha Waralaba 